\title{
UNRAVELLING THE LEGAL KNOTS AROUND INTER-COUNTRY ADOPTIONS IN DE GREE V WEBB
}

\section{ISSN 1727-3781}

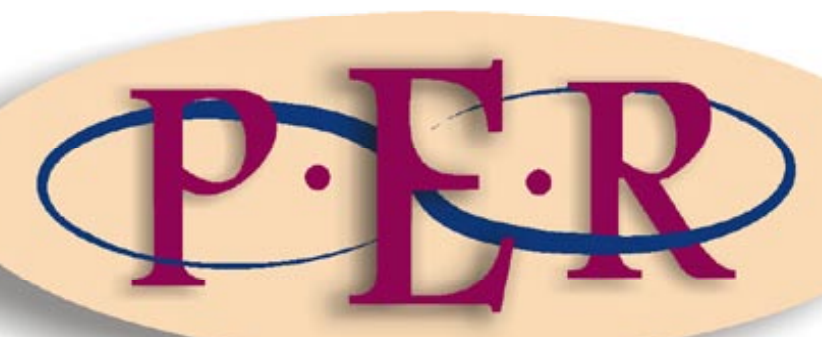

2007 VOLUME 3 


\section{UNRAVELLING THE LEGAL KNOTS AROUND INTER-COUNTRY ADOPTIONS IN DE GREE $V$ WEBB}

\section{P Moodley ${ }^{*}$}

\section{Introduction}

The four separate judgments by the learned Judges of Appeal in the matter of De Gree $v W e b b^{1}$ signifies to the reader the contentious terrain that intercountry adoptions has become in South African law. The first part of this contribution examines the legal conundrum within which we are trying to facilitate inter-country adoptions and the second examines the best interests of the child principle against the backdrop of the judgments in the De Gree matter.

\section{$2 \quad$ De Gree v Webb considered}

The facts of the case are that the appellants, an American couple of AfricanAmerican descent had been trying since 2005 to adopt baby $R$, who was found a few days after her birth abandoned in a bucket under a tree in the Roodepoort area. R was taken to a shelter, 'Baby Haven', run by the first and second respondents, American citizens, now resident in South Africa, and who since January 2005, have been appointed the foster parents of $\mathrm{R}$. The issue before the court is not the suitability of the appellants to adopt the child as it is clear that they are eminently suitable. The issue is really whether the procedure to secure the removal of the child from the Republic under the sanction of a custody and guardianship order from the High Court is indeed the best route to follow in the circumstances. The alternative route would have been to secure

* Director, Legal Administration, KZN Regional Office, Department of Justice and Constitutional Development. The author's views are her own and do not reflect that of the Department.

1 De Gree $v$ Webb 2007 SCA 87 (RSA). Hereafter referred to as the De Gree case. 
an inter-country adoption order via the Children's Court. It must be conceded that the current legal position in regard to inter-country adoptions is a grey area, evidenced by the four separate judgments in the De Gree case.

In addressing this issue, Theron AJA examined the adoption law and government's policy in respect of inter-country adoption. The Child Care Act 74 of $1983^{2}$ does not make provision for inter-country adoptions. Prior to the decision of the Constitutional Court in Minister for Welfare and Social Development $v$ Fitzpatrick and others, ${ }^{3}$ a South African child could only be adopted by a citizen and resident of South Africa. In the Fitzpatrick case, the prohibition against non-South Africans adopting a South African child was deemed to be inconsistent with section 28 of the Constitution. ${ }^{4}$ A practice had, in the interim, developed in South Africa wherein foreigners approach the High Court for orders of custody and guardianship in respect of young children that they wish to remove from the country. The judgment in Fitzpatrick did little to alter this practice.

Theron AJA examines the international principles to which South Africa is bound by virtue of acceding to the Hague Convention in 2003 and by ratifying both the United Nations Convention on the Rights of the Child (UNCRC) in 1995 and the African Charter on the Rights and Welfare of the Child in $2000 .^{5}$ Our Constitution decrees, however, that an international treaty shall not have effect until enacted into domestic legislation. ${ }^{6}$ The basic principles underlying these international documents provide important protection for children and cannot be disregarded solely, because our legislation giving effect to it is held up by the administrative process of drafting regulations in respect of same. Chapter 16 of the Children's Act 38 of $2005,{ }^{7}$ which was signed by the State

2 Hereafter referred to as the Child Care Act.

3 Minister for Welfare and Social Development v Fitzpatrick 2000 (3) SA 422 (CC). Hereafter referred to as the Fitzpatrick case.

4 Constitution of the Republic of South Africa 1996. Hereafter referred to as the Constitution.

5 Par 11-12.

6 S 231 of the Constitution.

7 Hereafter referred to as the Children's Act. 
President but is not yet fully in effect, ${ }^{8}$ will give legal recognition to the Hague Convention and will establish the central authority for inter-country adoptions. The chapter on children's courts is clear that all inter-country adoptions will be dealt with by the Children's Courts. Section 24 of the Children's Act is also clear that applications for guardianship may be made to the High Court and section 25 limits such applications to South African citizens and provides that a guardianship application by a non-South African citizen must be regarded as an inter-country adoption.

The learned judge's examination of the provisions of the Children's Act omitted to note that in terms of the definitions clause in the Children's Act, trafficking in children means:

(a) the recruitment, sale, supply, transportation, transfer, harbouring or receipt of children within or across the borders of the Republic -

(i) by any means, including the use of threat, force or other forms of coercion, abduction, fraud, deception, abuse of power or the giving or receiving of payments or benefits to achieve the consent of a person having control of a child; or

(ii) due to a position of vulnerability, for the purposes of exploitation; and

(b) includes the adoption of a child facilitated or secured through illegal means. $^{9}$

In paragraph 19 the appellants contended that one of the reasons for choosing the High Court route was that there were no regulations in place to govern inter-country adoptions. The learned judge's rejection of this contention must, with respect, be questioned. The factual position is that there are no existing regulations on inter-country adoptions pending the finalisation of the regulations in terms of the Children's Act. Whilst judges may indeed feel bound by the dicta in the Fitzpatrick decision that the Child Care Act contains sufficient safeguards 
for the protection of children generally, the fact remains that Child Care Act is silent on inter-country adoptions. The 'inter-country adoption policy' of the Department of Social Development unfortunately has no weight in the Children's Court that is tasked with the legal function of granting or refusing an application for an inter-country adoption. The Department of Social Development has established an office of the Central Authority (as per the Hague Convention) that purports to regulate inter-country adoptions. In practice, social workers bring applications for inter-country adoptions before Commissioners of Child Welfare who are expected to work within the parameters of the Child Care Act that does not specifically provide for intercountry adoptions.

The dissenting judgment of Heher $\mathrm{J}$ captures this point:

In my view any recognition of the 'Interim Central Authority' or the children's court as an implementer of inter-country adoptions in relation to the present application would be inappropriate. The law must be applied as it is, not as it may become, however probable the prospect. There are of course no regulations in place to regulate inter-country adoptions because there is, at the present time, no statute which authorises the content or making of such regulations... 10

Whilst the learned judge is correct that there is no act or regulations in place to administer inter-country adoptions, the Children's Court must be regarded as a legal 'implementer of inter-country adoptions' following on the Fitzpatrick judgment.

In Fitzpatrick, the Minister of Social Development requested the court to have the order of invalidity of section 18(4)(f) of the Child Care Act suspended for two years to enable the department to ensure that there would be adequate regulations and infrastructure in place to facilitate inter-country adoptions. The court refused to grant such suspension stating that the Children's Court is well empowered to grant an inter-country adoption. With respect, the court did not consider that the process of inter-country adoptions cannot be equated with 
domestic adoptions and in the absence of legislation and regulations enabling the Hague Convention on Inter-Country Adoptions, children's courts are operating in a vacuum. On a practical level, having to operate within the existing legal framework of the Child Care Act, and incorporate the expectations of the Fitzpatrick decision and the provisions of the new Children's Act, which has as yet, no regulations, presents some serious legal challenges.

One of the challenges faced by the process of an inter-country adoption operating within the ambit of the provisions and regulations of the Child Care Act is the legality of the exchange of money in adoption matters. The Child Care Act states that no person may

...give, undertake to give, receive or contract to receive any consideration, in cash or kind, in respect of the adoption of a child... 11

- and makes it a criminal offence if this provision is contravened.

The court in the Fitzpatrick case found that section 24 of the Child Care Act, is

...designed to deter the practice of child trafficking, making the exchange of consideration in an adoption a criminal offence.

A private adoption agency, Apostolic Faith Mission Welfare Council, in an article in the Star on April 28, 2002, is reported to have stated that they charge R16,000.00 for national and international adoptions. Abba Agency, in an interview with the author in 2005, indicated that they are affiliated to 72 pregnancy crisis centres countrywide and all these centres send babies to them for placement. They indicated that they have working agreements with members of EuroDopt, an organisation that facilitates the inter-country adoptions between Convention countries. Their fees per inter-country adoption is 2200 Euro or R18,000.00 at the time. The Children's Act does empower the Central Authority to authorise 'working agreements' between adoption agencies in South Africa and other Convention countries but the regulations governing 
these working agreements are not yet in place. Furthermore, contrary to the protection envisaged by Fitzpatrick that section 24 of the Child Care Act is designed to deter the practice of child trafficking, money is changing hands in inter-country adoptions.

The principle of subsidiarity, namely, that a child may only be placed for intercountry adoption after the possibilities for adoption in the country of birth have been considered and it is established that inter-country placement is in the child's best interests, presents another challenge in the Children's Court. This principle is found in article 21(b) of the UNCRC and article 17 of the United Nations Declaration on Social and Legal Principles Relating to the Protection and Welfare of Children. The Preamble to the Hague Convention states that -

inter-country adoption may offer the advantage of a permanent family to a child for whom a suitable family cannot be found in his or her state of origin.

This principle is, unfortunately, not stated anywhere in the Child Care Act. Section 40 of the Child Care Act requires Commissioners of Child Welfare to take into consideration the child's 'religion and culture'. It will be very difficult for the court to have regard to these criteria when considering an application to place a child in another country as South African culture is arguably, unique. The argument of Heher JA on the question of subsidiarity is compelling indeed; that the child concerned was abandoned at birth, has no experience of a religious or cultural background other than that of the first and second respondents which is exactly the same as that of the applicants. The learned judge's contention that the principle of subsidiarity is "very largely reduced in importance by these uncontested facts", however loses sight of the fact that no effort was made to secure a home for the child within South Africa. The principle, as set out in the Preamble to the Convention, presupposes that the initial enquiry must be whether or not a suitable home is available for the child in the country of origin. It is only when this is exhausted that an adoption outside the country should be considered. 
Theron AJA, in denouncing the efforts of the third respondent whose duty it was to attempt to secure suitable care for the child within South Africa, raises the point of the voice of the child. The learned judge says:

Ruth's voice has not been heard in this application. The third respondent, who ought to have represented Ruth's best interests, has failed to do so. ${ }^{12}$

And in paragraph 25:

... the third respondent, whose function it was to do so, aligned themselves with this application from the outset.

Ponnan JA, echoes the need for the voice of the child to be heard in an application of this nature and finds that the appointment of a curator ad litem was indispensable in this case. He is clear in his assessment that the third respondent had "failed the child". ${ }^{13}$

It is clear that the roles of the child protection agencies and those facilitating the adoption services should remain separate and distinct. As Theron AJA has pointed out, the child protection agency that is tasked with ensuring the protection of the child and an outcome that is in the best interests of the child should not be accredited with providing inter-country adoption services as this will definitely blur the boundaries. A reading of section 258(2) of the Children's Act together with section 259 permits this very anomaly to occur. ${ }^{14}$ The constitution and regulation of the functions of the Central Authority may be the only check in this untenable situation.

It is exactly because these loopholes exist that any court needs to be extra vigilant in allowing a child to be removed from the country. In quoting the

12 At par 21.

13 Ponnan JA at par 95.

14 S 258(2) states: "Any powers or duties of the Central Authority in terms of Articles 15 to 21 of the Convention and sections 261(3) and (4), 262(3) and (4), 264(2) and 265(2) may, to the extent determined by the Central Authority, be performed by:

a) another organ of state;

b) a child protection organisation accredited in terms of section 259 to provide intercountry adoption services..." 
Constitutional Court in Fitzpatrick, Theron AJA emphasises the greater burden that applicants face in such applications -

until the new child care legislation is in operation and infrastructure and international agreements are put in place, prospective adoptive applicants 'will have a greater burden in meeting the requirements of the Child Care Act than they will have thereafter'...

The debate of what was in the best interests of little R clearly illustrated how the standard can indeed take on different shades:

- The appellants argued that if the application were to be refused, the court would be placing the interests of the child secondary to departmental policies and procedures.

- In Fitzpatrick, Goldstone J stated that:

....it is necessary that the [best interests] standard should be flexible as individual circumstances will determine which factors secure the best interests of a particular child. ${ }^{15}$

- Heher J found that:

...while the interests of children generally are important they are only so to the extent that the child in this case will benefit or be adversely affected by the furtherance or limitation of those interests because this matter concerns the child $\mathrm{R}$ and no other. The peculiar facts of this case cannot be determinative or even persuasive of the rights of any other child whose interests are not the same. ${ }^{16}$

The court, however, was not persuaded by this train of thought. After considering the best interests standard as set out in articles 3 and 21 of the UNCRC, and the Hague Convention, the court concluded that -

these international instruments seek to protect the best interests of the child by ensuring, inter alia, that inter-country adoptions are conducted in a responsible and protective manner with the aim of eliminating the various abuses which have been associated with inter-country adoptions. 
With respect, not only was this a more holistic and wide interpretation of the standard, but one that recognises the room for different types of abuse associated with inter-country adoptions which include the trafficking of children.

The court was persuaded by arguments by the Centre for Child Law that entered the matter as amicus curiae. Ann Skelton, counsel for the Centre for Child Law, argued in written submissions before the court -

By failing to proceed in terms of the Child Care Act, the Children's Court is bypassed and South African children are removed from the country without a formal adoption having been sanctioned by the relevant local authorities. This places the children in a potentially vulnerable position, having left South Africa in terms of a guardianship and custody order granted in favour of potential adoptive parents.

She argues further that once a child has been removed from the country, the South African courts lose its authority as upper guardian of that child. The child is thus left in a 'legal limbo', entirely dependant on the goodwill of the prospective adopters. This is perhaps the most compelling argument of what is in the best interests of a child facing an inter-country adoption. Certainty of the finalisation of the legal process of adoption in the child's own country of birth will remain the safest means of ensuring the protection of the child outside the borders of the country of birth. This is what the finalisation of an adoption in the Children's Court will ensure for the baby R, in this case, and for every other child facing the prospect of an inter-country adoption. As the sending country, it is also important for South Africa to send off the child with dignity and secure in the knowledge that the child's rights are protected, and not to abandon South African children to the unknown legal processes of the receiving country.

Ponnan JA, in a judgment that may sometimes only be described as lyrical prose, continues that whilst the "immediate allure of her being placed with the appellants is seductively appealing", ${ }^{17}$ it falls short of the international principle of subsidiarity as the evidence fell short of establishing that there is an absence 
of prospective parents in this country for the child. As Ponnan JA concludes after examining the forum chosen by the appellants and the consequence that an order for the removal of the child to the United States will necessitate,

...the child will be in a state of legal limbo. The security which comes with an adoption order is what the Hague Convention requires and the best interests of the child demands. To fashion relief that is less than that accorded to her by the Convention, is to my mind, the very antithesis of the best interests of the minor child. ${ }^{18}$

It is clear from the judgment in De Gree that neither the appellants; the amicus curiae; nor any of the learned judges made any reference to the best interests of the child standard as set out in section 7 of the Children's Act. ${ }^{19}$ Certainly, a reading of same indicates that the various clauses therein may have assisted the different parties in their respective efforts to give meaning to the elusive standard. Section 7 of the act lists the factors that must be taken into consideration when the best interests of the child standard must be applied. Some of the factors that are listed in the act and that may have assisted the parties in their respective arguments are the following:

(i) the likely effect on the child of any change in the child's circumstances, including the likely effect on the child of any separation from -

a) both or either of the parents;

b) any brother or sister or other child, or any other care-giver or person, with whom the child has been living;

(ii) the need for the child -

a) to remain in the care of his or her parent, family and extended family; and

b) to maintain a connection with his or her family, extended family, culture or tradition;

18 Ponnan JA at par 98.

19 S 7 was one the sections of the Children's Act that came into effect on 1 July 2007 as per Procl R13 of 2007, signed on the 28 June 2007. 
(iii) the need for the child to be brought up in a stable family environment and, where this is not possible, in an environment resembling as closely as possible a caring family environment;

(iv) which action or decision would avoid or minimise further legal or administrative proceedings in relation to the child.

\section{Conclusion}

In traversing the area of inter-country adoption law against the background of the provisions of the international treaties, to which we are party, and the new Children's Act, which is partly promulgated, we get a glimpse of what is ahead of us for the next few years as we give effect and meaning to the substance of the new legislation. The guidance and direction of the courts will be required in a clear and decisive manner even treading through murky waters as the majority judgment in this case did. Pending the promulgation of the regulations on the Children's Act, especially in regard to inter-country adoptions, the relevant departments must work co-operatively to implement the practice guidelines $^{20}$ that should aim to encourage rather than dissuade the legal profession from the simpler and more cost effective procedures contained in the Children's Act. ${ }^{21}$

20 Second Draft Guidelines for Inter-country Adoption, Nov 2006 - Department of Social Development.

21 See also Burman (ed) Fate of the child; Davel (ed) Introduction to Child Law; Van Heerden, Cockrell and Keightley (eds) Boberg's Law of Persons. 


\section{Bibliography}

Burman (ed) Fate of the child

Burman S (ed) The fate of the child: Legal decisions on children in the new South Africa (Juta Kenwyn 2003)

Davel (ed) Introduction to Child Law

Davel CJ (ed) Introduction to Child Law in South Africa (Juta Kenwyn 2000)

Van Heerden, Cockrell and Keightley (eds) Boberg's Law of Persons Van Heerden B, Cockrell A and Keightley R (eds) Boberg's Law of Persons and the Family $2^{\text {nd }}$ ed (Juta Kenwyn 1999)

\section{Register of cases}

De Gree v Webb 2007 SCA 87 (RSA)

Minister of Welfare and Population Development $v$ Fitzpatrick and others 2000 (3) SA 422 (CC)

\section{Register of international treaties}

African Charter on the Rights and Welfare of the Child Hague Convention on Inter-country Adoptions

United Nations Convention on the Rights of the Child

United Nations Declaration on Social and Legal Principles Relating to the Protection and Welfare of Children

\section{Register of legislation}

Child Care Act 74 of 1983

Children's Act 38 of 2005

Constitution of the Republic of South Africa 1996

Guardianship Act 192 of 1993

Procl R13 Government Gazette 3003029 June 2007 


\section{List of abbreviations}

par paragraph(s)

procl proclamation

s $\quad \operatorname{section(s)}$

UNCRC United Nations Convention on the Rights of the Child 